\title{
CASE COMMENT: PEEL V. GREAT ATLANTIC PACIFIC CO. OF CANADA ET AL.
}

\author{
IVAN F. IVANKOVICH*
}

The author undertakes a critical analysis of the Ontario High Court decision in Peel (Regional Municipality) v. Great Atlantic \& Pacific Co. of Canada et al. to ascertain whether the decision. which declared amendments to the Retail Business Holidays Act in Ontario to be unconstitutional, can be supported on any logical or precedential basis. After reviewing recent appellate court case law dealing with the issue of provincial/municipal Sunday closing legislation and outlining the substance of the Peel decision, the author concludes that the case should be overturned by the Ontario Court of Appeal. (Note: Since the writing of this article the Peel decision in fact has been overturned.) He first argues that the Ontario Act does not infringe the constitutional guarantees of religious freedoms contained in the Charter because the Act does not impose $a$ burden of sufficient significance or constitute a significant infringement on the religious practices of non-Sunday observing retailers, employers or customers as required by the test set out by the Supreme Court in Edwards Books. If this argument fails, the author suggests that the prohibition and amended exemptions in the Act should be upheld as reasonable limits under s. I of the Charter, applying the "pressing and substantial concern" and "proportionality" tests set out in Ewards Books. The author concludes by discussing the potential impact of the Peel decision on Sundayclosing legislature schemes which incorporate municipal option features, as found in several provinces, including Alberta.
L'auteur entreprend une analyse critique de la décision rendue par la Haute Cour de l'Ontario dans Peel (Regional Municipality) c. Great Atlantic \& Pacific Co of Canada et al. afin de déterminer si l'arrêt, qui déclarait que les amendements apportés au Retail Business Holidays Act de l'Ontario étaient inconstitutionnels, peut se défendre par la logique ou la jurisprudence. Après avoir examiné le droit jurisprudentiel récent des Cours d'appel relatif aux lois provinciales/ municipales sur le chômage du dimanche et la substance de la décision Peel. l'auteur conclut que l'arrêt devrait être renversé par la Cour d'appel de l'Ontario (c'est en fait ce qui est advenu depuis lors). Il soutient d'abord que r'Ontario Act ne viole pas la liberté de religion garantie par la Charte parce qu'il n'impose pas une obligation d'importance suffisante et qu'il ne constitue pas une atteinte appréciable aux pratiques religieuses des détaillants, employés ou clients qui ne chôment pas les dimanches, comme l'exige l'épreuve présentée par la Cour suprême dans Edwards Books. Si cet argument n'est pas retenu, l'auteur suggère que l'interdiction et les dispenses modifiées que contient la loi soient maintenues en tant que limites raisonnables visées à l'art. I de la Charte, et conformément aux épreuves de "considération pressante et importante et de "proportionnalité énoncées dans Edwards Books. L'auteur conclut en parlant des conséquences potentielles de la décision Peel sur les projets de loi relatifs au chomage du dimanche qui incorporent des éléments optionnels au niveau municipal et que l'on retrouve dans plusieurs provinces, dont l'Alberta.

\section{TABLE OF CONTENTS}

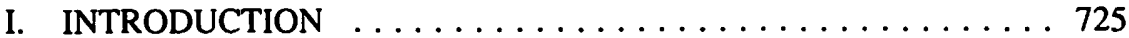

II. SUNDAY CLOSING CASELAW $\ldots \ldots \ldots \ldots \ldots \ldots \ldots \ldots$

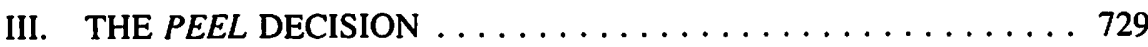

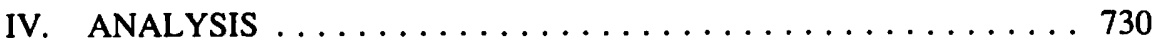

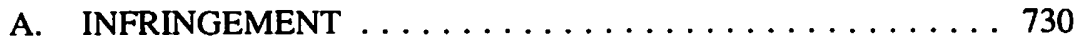

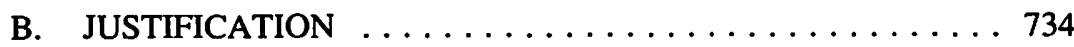

v. CONCLUSION $\ldots \ldots \ldots \ldots \ldots \ldots \ldots \ldots \ldots \ldots \ldots \ldots \ldots \ldots \ldots$

Associate Professor, Faculty of Business, University of Alberta. 


\section{INTRODUCTION}

Sunday-closing laws of one type or another have been enacted in all ten provinces. While the specifics comprise a peculiarly Canadian mosaic, certain general patterns emerge. With the exception of Alberta, where the decision and the extent to prohibit Sunday shopping is left entirely to the municipalities, the other nine provinces have enacted general prohibitions with varying exceptions. ${ }^{1}$

Since the proclamation of the Canadian Charter of Rights and Freedoms the validity of this type of legislation has been adjudicated twice by the Supreme Court of Canada. In R. v. Big M Drug Mart Ltd., ${ }^{2}$ the federal Lord's Day Act ${ }^{3}$ was invalidated because its religious purpose contravened section 2(a) of the Charter. In $R$. v. Edwards Books \& Art $L t d .{ }^{4}$ provincial Sunday-closing legislation was upheld on the ground that its secular purpose was to provide a uniform rest day, notwithstanding that it indirectly infringed upon the religious freedom of certain non-Sunday observing retailers. On two occasions thereafter the Supreme Court of Canada refused leave to appeal from appellate decisions upholding the validity of provincial municipal Sunday-closing laws. ${ }^{5}$ As a result, one should have thought that $C$ harter challenges to the validity of legislation regulating the days and hours during which business is permitted was no longer problematic. It appears, however, that the Supreme Court of Canada may soon be invited yet again to reopen the legal debate over Sunday shopping in that context.

1. Holiday Shopping Regulation Act, S.B.C. 1980, c. 17; Municipal Government Act, R.S.A. 1980, c. M-26, s. 241 [re-en. 1985, c. 43, s. 31]; The Urban Municipality Act, S.S. 1983-84, c. U-11 as am., s. 121; The Retail Businesses Holiday Closing Act, S.M. 1987-88, c. 7, Cap. R 120; Retail Business Holidays Act, R.S.O. 1980, c. 453, as am.; An Act Respecting Commercial Establishments Business Hours, R.S.O. 1977, c. H-2; Sunday Observance Act, R.S.Q. 1977, c. 0-1; Days of Rest Act, S.N.B. 1985, c. D-4.2; Retail Business Uniform Closing Day Act, S.N.S. 1985, c. 6 as am.; Days of Rest Act, S.P.E.I. 1985, Cap. 12; The Shops Closing Act, S.N. 1977, c. 107. Certain classes of goods/services, the most commonly recurring of which are newspapers, tobacco products, gasoline, convenience food products and pharmaceuticals, are universally exempted. A "small business" exemption whereby stores employing less than a certain number of employees and/or utilizing less than a certain square footage for serving the public is recognized in B.C., Sask., Man., Ont., Que. and N.B. Broad religious exemptions permitting retailers to open on Sundays providing they are closed on some other day of the week are enacted in Ont. (1989), N.B. and P.E.I. Sask. restricts its religious exemption to small businesses and Man. limits its application to those retailers who close on Saturdays. No religious exemptions are enacted in B.C., Que., N.S. and Nfld. Lastly, municipal option provisions permitting local by-laws to depart in whole or in part from the general prohibition are enacted in B.C., Sask., Ont. (1989), N.B. and Nfld. [1985] 1 S.C.R. 295, 37 Alta. L.R.(2d) 97, [1985] 3 W.W.R. 481, 18 C.C.C. (3d) 385, 18 D.L.R. (4th) 321, 13 C.R.R. 64, 85 C.L.L.C. 14,023, 60 A.R. 161, 58 N.R. 81 (S.C.C.).

3. R.S.C., 1970, C. L-13.

4. [1986] 2 S.C.R. 713, 55 C.R. (3d) 193 (sub. nom. R. v. Videoflicks Ltd.), 30 C.C.C. (3d) 385 (sub nom. Edwards Books \& Art Ltd. v. R.; R. v. Nortown Foods Ltd.), 35 D.L.R. (4th) 1, 28 C.R.R. 1, 87 C.L.L.C. $14,001,19$ 0.A.C. 239,71 N.R. 161.

s. London Drugs Ltd. v. Red Deer (City) (1988), 61 Alta. L.R. (2d) 1 (C.A.), affirming 55 Alta. L.R. (2d) 56 (Q.B.) - leave to appeal to S.C.C. refused 19th September 1988: (1988), 61 Alta. L.R. (2d) lii, note; $R$. v. Paul Magder Furs Ltd. (1989), 69 0.R. (2d) 172, 45 C.R.R. 344, 49 C.C.C. (3d) 267, 33 O.A.C. 81 (C.A.) - leave to appeal to S.C.C. refused 9 November 1989: (1990), 70 0.R. (2d) X, note, (1989), 45 C.R.R. 344n. 
Ontario retailers were legally open for business on Sundays for 9 months as a result of the Ontario High Court decision in Peel (Regional Municipality) v. Great Atlantic \& Pacific Co. of Canada et al. ${ }^{6}$ Just prior to the facts giving rise to the litigation, Ontario purportedly "liberalized" its Retail Business Holidays Act ${ }^{7}$, from that which was upheld by the Supreme Court in Edwards Books by enacting amendments ${ }^{8}$ broadening the exemption for non-Sunday observing retailers and decentralizing the Sunday closing issue through a municipal option provision. This latter aspect was primarily responsible for Mr. Justice Southey's declaration that the amended Act was constitutionally invalid. If correct, that reasoning would jeopardize existing Sunday-closing legislative schemes in Alberta, ${ }^{9}$ Saskatchewan, ${ }^{10}$ New Brunswick, ${ }^{11}$ and Newfoundland. ${ }^{12}$ As this edition of the Alberta Law Review went to press, the Ontario Court of Appeal reversed, upheld the constitutional validity of the amended legislation and again shut the door on Sunday shopping in Ontario. As present indications are that leave to appeal to the Supreme Court of Canada will be sought the issues arriving from Mr. Justice Southey's decision remain timely.

My purpose in this commentary is to critically analyze the trial decision in Peel in order to ascertain whether any logical or precedential basis exists to support its anomalous result. In order to do so, it is first necessary to briefly review the recent and, theretofore, reconcilable appellate caselaw relating to provincial/municipal Sunday closing legislation.

\section{SUNDAY CLOSING CASELAW}

In Edwards Books,$^{13}$ the Supreme Court of Canada scrutinized the purpose and effect of Ontario's Retail Business Holidays Act. The relevant provision of the Act then required retail businesses to close on Sundays unless the business employed less than seven employees to serve the public, used less than 5,000 square feet to display and sell merchandise and was closed to the public on the preceding Saturday [the "Saturday-closing" exemption]. ${ }^{14}$ One of the businesses charged with violating the Act was a large retail operation owned by Orthodox Jews whose religion required them to be closed on Saturdays. In considering the effect of the legislation, Dickson C.J.C., writing for the majority of the Supreme Court of Canada, concluded that the Act infringed freedom of religion because it imposed a "significant" ${ }^{\text {"15 }}$ economic burden on Saturdayobserving retailers who, unlike their Christian competitors, would have to close on two

(1990), 73 O.R. (2d) 289 (Ont. H.C.).

R.S.O. 1980, c. 326 as am. Hereinafter, in the text, the amended Act may be referred to as the Ontario Act or R.B.H.A., as the case may be.

Act to Amend the Retail Business Holidays Act, S.O. 1989, c. 3.

Supra, note 1.

Ibid.

Ibid. s. 5.

Ibid. ss. 13-15.

Supra, note 4.

R.S.O. 1980 , c. 453 , s. 3 [am. 1986 , c. 64 s. 62 ; am. 1987 , c. 36 , s. 1 ].

The test posited by the Chief Justice (Chouinard and Le Dain JJ. concurring) for determining whether the effect of legislation violates s. 2(a) of the Charter is ".....whether it significantly impinges on the freedom to manifest or practise religious beliefs." (at p. 762 [S.C.R.], p. 36 [D.L.R.]). 
days a week unless they fell within one of the limited statutory exemptions. ${ }^{16}$ In order to determine whether or not the Ontario Act was a reasonable limit within s. 1 of the Charter, the Chief Justice formulated the following justificatory test which he derived from previous S.C.C. decisions: ${ }^{17}$

Two requirements must be satisfied to establish that a limit is reasonable and demonstrably justified in a free and democratic society. First, the legislative objective which the legislation is designed to promote must be of sufficient importance to warrant overriding a constitutional right. It must bear on a "pressing and substantial concern." Second, the means chosen to attain those objectives must be proportional or appropriate to the ends. The proportionality requirement, in turn, normally has three aspects: the limiting measures must be carefully designed, or rationally connected, to the objective; they must impair the right as little as possible; and their effects must not so severely trench on individual or group rights that the legislative objective, albeit important, is nevertheless outweighed by the abridgment of rights.

With respect to the first requirement, Dickson C.J.C. referred to but found it unnecessary to resort to dated statistical evidence ${ }^{18}$ in order to judicially recognize that the legislative objective of establishing a common pause day was directed at a "pressing and substantial concern". ${ }^{19}$ Significantly, he regarded its importance as "self-evident". ${ }^{20}$ Concerning the proportionality requirement, he held that there was a rational connection between legislative objective and means notwithstanding that the Act focused exclusively on the retail industry and distinguished between types of retail businesses in its scheme of exemptions. Importantly, he emphasized that the nature of the choices and compromises to be made were matters best left to the legislatures. ${ }^{21}$ Lastly, he directed his attention to the third aspect of the proportionality test, viz., whether the infringement on the religious freedom of certain non-Sunday observing retailers was proportionate to the legislative objective, concluding that the Act could be upheld under s. 1 because it incorporated a "serious effort" to accommodate the religious freedom of Saturday observers. ${ }^{22}$ Underlying his judgment is the view that some legislative attempt to minimize adverse effects was mandatory if a statute is to pass the proportionality test. ${ }^{23}$

Both La Forest J. and Wilson J. agreed with the Chief Justice on this point. Mr. Justice Beetz (McIntyre J. concurring) was of the view that the Act did not violate s. 2(a) on the ground that it was not the legislation per se that caused economic harm but, rather, the Saturday observer's décision to adhere to his religious beliefs.

17. Supra, note 4, at p. 768 (S.C.R.), p. 41 (D.L.R.).

18. Report on Sunday Observance Legislation(Ontario,1970): ibid. at p. 769 (S.C.R.), p. 42 (D.L.R.).

19. Edwards Books, ibid, at p. 770 (S.C.R.), 42-43 (D.L.R.). This was also expressly the view of La Forest J.: see p. 793 (S.C.R.), p. 66 (D.L.R.).

lbid.

Ibid. at p. 772 (S.C.R.), p. 44 (D.L.R.).

Ibid. at p. 783 (S.C.R.), p. 52 (D.L.R.).

Wilson J. was of a similar view but found that the small business exemption did not go far enough because it was only available to certain members of the group: see pp. 808-809 (S.C.R.), pp. 60-61 (D.L.R.). La Forest J., on the other hand, was of the opinion that the statute would be valid without the exemption insofar as the latter was exclusively a legislative choice: see pp. $795-796$ (S.C.R.), pp. 67-68 (D.L.R.). Beetz J. (McIntyre J. concurring) did not find it necessary to discuss the application of s. 1 of the Charter: see p. 788 (S.C.R.), p. 56 (D.L.R.). 
The first major post-Edwards Books decision was London Drugs Ltd. v. City of Red $D e e r^{24}$ which dealt with a Sunday-closing by-law enacted pursuant to the permissive powers contained in Alberta's Urban Municipality Act. ${ }^{25}$ The by-law required closure on Sunday unless a business closed for 24 hours in one of the six days immediately following Sunday. This feature led Cote J.A., delivering the judgment of the Alberta Court of Appeal, to conclude that the by-law did not have any effect which infringed the freedom of religion guaranteed in $s$. 2(a) because it treated all businesses equally by allowing them to choose the day on which to close. ${ }^{26}$ Leave to appeal to the S.C.C. was refused on October 20, 1988.

Within a matter of weeks, the British Columbia Court of Appeal, in R. v. Canada Safeway Ltd. ${ }^{27}$ declared the Sunday-closing provisions in that province's Holiday Shopping Regulation Act ${ }^{28}$ unconstitutional. Like the Ontario legislation upheld in Edwards Books, the B.C. Act contained a "small business" exemption restricted basically to small convenience stores selling "foodstuffs, antiques, newspapers, periodicals, handicrafts and sundries". Unlike the Ontario legislation, however, the B.C. Act contained no further exemptions which could be utilized by non-Sunday observing retailers. The absence of this type of exemption led Seaton J.A., in delivering the judgment of the court, to conclude that the B.C. Act, unlike Ontario's, did not impair religious rights "as little as possible" and, thus, did not pass the proportionality test articulated by Dickson C.J.C. in Edwards Books. A similar conclusion was reached by the Saskatchewan Court of Appeal in $R$. v. Westfair Foods Ltd. et al $l^{29}$ with respect to a Sunday-closing by-law without any "religious" exemptions enacted under Saskatchewan's Urban Municipality Act. ${ }^{30}$

Most recently, in R. v. Paul Magder Furs Ltd., ${ }^{31}$ the Ontario Court of Appeal had occasion to reconsider the identical legislation that was upheld by the S.C.C. in Edwards Books. This time, however, as the factual context arose subsequent to April 17, 1985, the constitutionality of Ontario's Retail Business Holidays Act was challenged on the basis that it infringed retailers' equality rights under $\mathrm{s}$. 15 of the Charter because certain retail establishments were allowed to be open on Sundays [the "small business" or limited "Saturday-closing" exemptions]; and that, as well, it was open to a municipality to enact by-laws exempting stores selling certain kinds of goods in tourist areas from the

24. Supra, note 5.

25. Supra, note 1 .

26. Ibid. at p. 15.

27. (1988), 37 B.C.L.R. (2d) 199, [1989] 5 W.W.R. 122 (B.C.C.A.).

28. Supra, note 1.

29. (1989), 80 Sask. R. 33 (Sask. C.A.) rev'g in part (1988), 58 Sask. R. 274 (Sask. Q.B.).

30. The court declared the provisions inoperative only to the extent they violated the religious freedom of retailers who, for religious reasons, closed their stores on Saturday. Saskatchewan subsequently enacted a broad sabbatarian exemption: see Urban Municipality Amendment Act 1986 (No. 2), S.S. 1986 , c. 38.

31. Supra, note 5. 
application of the Act [the "tourist area" exemption]. Assuming an infringement of $s$. $15,{ }^{32}$ the Ontario Court of Appeal unanimously upheld the legislation as a reasonable limit under s. 1 primarily on the basis that the same considerations which led the S.C.C. to find that the Ontario Act was a reasonable limit against an infringement of religious freedom under s. 2(a) applied equally to the alleged infringement under s. 15. The court used the occasion to expressly disapprove of the attempt to re-litigate on the basis of new evidence submitted to establish that the factual basis for the S.C.C. findings in Edwards Books was now outdated. ${ }^{33}$ Leave to appeal to the S.C.C. was refused on November 9, 1989.

\section{THE PEEL DECISION}

As the Paul Magder Furs case was making its way through the Ontario courts, the province enacted two major amendments to its Retail Business Holidays Act. ${ }^{34}$ The first of these repealed the "Saturday-closing" exemption and replaced it with a new sabbatarian exemption applicable to all non-Sunday observing retailers regardless of size. ${ }^{35}$ Section 5 of the amended Act states that a retail business may be open on Sunday if it "is always closed to the public throughout another day of the week by reason of the religion of the owner of the retail business". The second major amendment repealed the "tourist industry" exemption which had empowered municipalities to exempt retailers from Sunday closing if the business was "essential for the maintenance or development of a tourist industry", and replaced it with a broader "municipal option" exemption permitting municipalities, upon complying with certain procedural requirements, to make their own Sunday opening or closing by-laws. ${ }^{36}$ Under s. 4 of the amended Act, these by-laws could be made to apply to only certain parts of a municipality, certain holidays, certain hours of the day or periods of the year and could classify retail business establishments by size, number of persons employed, character of business, geographic location or any other criteria. After the amendments were proclaimed, the Regional Municipality of Peel

32. It was conceded by the Crown that the R.B.H.A., in its application to non-Sunday observers, infringed the equality rights of the accused. The Ont. C.A. proceeded on that assumption although it expressed some doubt that distinctions involving commercial regulation constitute discrimination contrary to s. 15 (1) of the Charter: ibid. at p. 182 (O.R.).

33. The court specifically adopted (at p. 185) the following passage in the reasons for judgment of La Forest J. in Edwards Books:

It is undesirable that an act be found constitutional today and unconstitutional tomorrow simply on the basis of the particular evidence of broad social and economic facts that happens to have been presented by counsel. We should avoid this possibility when reasonably possible, particularly in these early days of Charter litigation when all are feeling their way regarding the manner in which Charter litigation is to be conducted.

34. Supra, note 8.

35. This amendment was enacted to eliminate the infringement of s. 2 religious freedom identified in Edwards Books and to pre-empt other s. 15 challenges to the limited scope provided by the previous "Saturday closing" exemptions: see, e.g. R. v. Nouveautes Capiral Liee. (1987), 34 C.C.C. (3d) 67. 73 (Que. S.C.).

36. The new exemption was prompted by the perceived abuse of its predecessor. As noted by Southey J., at p. 308, some councils simply exempted the entire municipality while others exempted single stores, areas or classes of stores having no more connection with tourism than their non-exempt counterparts. 
and the Attomey General of Ontario applied for a compliance order requiring local supermarkets to close on Sundays. The application failed and the respondents were successful in obtaining a declaration that the amended Act was unconstitutional and of no force or effect.

Mr. Justice Southey found that the new sabbatarian exemption did not alleviate the adverse effects of Sunday closing on non-Christian retailers and on non-Sunday-observing employees and consumers. Acknowledging that "the responsibility of balancing the conflicting interests of different groups was that of the Legislature, not the courts, ${ }^{137}$ he upheld the new sabbatarian exemption under s. 1 of the Charter, ruling that it "reflect(ed) a reasonable trade-off between different possible schemes". ${ }^{38}$ The "municipal option" exemption fared less favourably. According to Southey J., it represented a municipal "carte blanche", giving municipalities "unprincipled power. ${ }^{39}$ As such, in his view, it failed to meet both requirements of the justificatory test articulated in $E d w a r d s$ Books, i.e., (1) the legislative objective could not be seen to bear on a "pressing and substantial concern" because the Act gave municipalities the power to nullify the objective via the "municipal option" exemption and (2) there was no rational connection between legislative objective and means because that exemption left it entirely up to individual municipalities to determine opening/closing criteria or to proceed without establishing any criteria. With terse commentary, he also found that the "municipal option" exemption violated s. 15 equality rights and that such discrimination, for the very same reasons, could not be saved under s. $1 .^{40} \mathrm{He}$ concluded by declaring the entire Act unconstitutional because, in his view, the exemption was so integral to the Act that the Legislature might not have enacted the legislation without it.

\section{ANALYSIS}

Two issues must be addressed in assessing the correctness of the Peel decision of the Ontario High Court. First, does the amended Ontario Act infringe Charter rights guaranteeing freedom of religion and/or freedom from discrimination on the basis of religion? If not, $P e e l$ is wrongly decided quite apart from the justificatory issue. Second, and assuming an infringement, can that infringement nevertheless be justified under s.1?

\section{A. INFRINGEMENT}

Not every burden on religious practices is offensive to the constitutional guarantee of religious freedom. The test to determine whether the impact of legislation constitutes an infringement was set out by the Supreme Court of Canada in Edwards Books, viz., does the legislation "significantly impinge on the freedom to manifest or practise religious beliefs". ${ }^{41}$ Understandably, in that case, the court found that the economic pressure imposed by Sunday-closing legislation on non-exempt Jewish retailers to abandon the

\footnotetext{
Peel, supra, note at 304.

Ibid. at 306.

Ibid. at 308-309.

Ibid. at 310 .

Supra, note 4, at 762 (S.C.R.), 36 (D.L.R).
} 
observance of a Saturday sabbath met the "significant infringement" test. In Peel, Mr. Justice Southey supported his conclusion that the amended Ontario legislation infringed freedom of religion by pointing specifically to its impact on three groups: (1) nonChristian retailers, (2) non-Sunday-observing employees, and (3) non-Sunday-observing consumers.

His Lordship's commentary with respect to the burden on non-Christian retailers is, with respect, in part inaccurate and, on the whole, unconvincing. It will be recalled that the new sabbatarian exemption in purpose and effect attempts to eliminate the adverse impact of a weekly pause day on retailers' religious freedom by permitting all affected retailers to open on Sundays and close throughout another day of the week in accordance with their religious beliefs. Notwithstanding this, Southey J. found that the Act imposed a significant burden on non-Christian retailers because it designated certain other days in addition to Sundays as "holidays" within the meaning of the Act, a common feature of most provincial Sunday-closing legislative schemes: ${ }^{42}$

...[T]he amendment does not alleviate in any way the burden on non-Christian retailers of being compelled to remain closed on the Christian religious holidays of Christmas Day and Good Friday, as well as on their own holy days. Similar considerations apply to the compulsory closing under the Act on the 26th of December, which is related to the celebration of Christmas, and on New Year's Day, which has counterparts in non-Christian religions on days other than January 1st. I am not persuaded that the burden of closing on four additional days each year is trivial or insubstantial.

It should be noted, at the outset, that the 26th December is unrelated to the religious celebration of Christmas. The nomenclature "Boxing Day" historically derives from the fact that servants and minor employees used to carry little "boxes" on this day each year and make the rounds of all the people who might owe them any tips or year-end bonuses. ${ }^{43}$ Over the years the "holiday" evolved into one of commercial significance and permitted merchants to engage in the secular activity of taking inventory and re-"boxing" merchandise after an intense period of equally secular seasonal shopping by their clientele. At present, the day itself possesses no special religious significance to any Christian denomination. While the "religious" origin of New Year's Day is, at best, unclear, ${ }^{44}$ the first day of the year in Canada has long since taken on a secular hue, as wit., the widespread celebrations devoid of religious content which herald the advent of that day. On the other hand, the Christian origins and present-day significance of Christmas and Good Friday cannot be denied, although there is judicial support that the former has also

Peel, supra, note 6 at 297. B.C., Sask., Man., Ont., Que., N.B., N.S., Nfld. designate certain other days in addition to Sundays as "holidays". Alberta leaves the designation of "days that businesses are required to close", if any, to the municipalities. The P.E.I. Act is limited to Sunday closings. H.V. Harper, Days and Customs of All Faiths. New York: Fleet Publishing Corp., 1957 at 323. Under the Julian calendar the year began on March 25th. It is likely that this idea of New Year's Day was a carry-over from the Jewish custom of starting the year at the time of the full moon after the spring equinox. When the Gregorian calendar came into use, New Year's Day was moved up to its present date: see Harper, ibid. at p. 17. 
become a non-religious holiday ${ }^{45}$ In any event, the economic burden imposed by the legislation as a whole upon non-Christian retailers must be placed in its proper perspective. The Ontario Act designates 60 "holidays", 52 of which are Sundays. Of these, the sabbatarian exemption effectively eliminates any potential burden. Six of the eight remaining "holidays" are not Christian religious holidays, and therefore, not in issue. The Act, then, imposes on non-Christian retailers the added burden of having to close on only two additional holidays which also correspond to Christian religious holidays. Looked at another way, the legislation permits retailing on 305 of the 365 days in any average year. Of those 305 , the additional burden imposed on the non-Christian retailer represents substantially under $1 \%$, an incidence, it is suggested, which is both "trivial" and "insubstantial" and which fails to constitute a "significant infringement" within the meaning of Edwards Books. Alternatively, a minor severance could have eliminated the burden entirely.

In all the cases, heretofore, where an infringement of the Charter guarantee of religious freedom was established, it was on the primary basis that the legislation imposed a significant economic burden on non-Sunday-observing retailers by making it more expensive for them to practise their religion in comparison with Sunday-observing competitors. Prior to the Peel decision, in two cases relied upon by Mr. Justice Southey, the suggestion emerged that, in addition to the economic burden on retailers, the legislation's effect on consumers and employees must also be considered. In Edwards Books, Dickson C.J.C. appears, however, only to have referred to the burden imposed on Saturday-observing consumers as an afterthought subsequent to his detailed discussion of the economic burden actually imposed on Saturday-observing retailers. In his own words, he was merely "prepared to assume....that the burden on Saturday-observing consumers is substantial and constitutes an abridgement of their religious freedom". ${ }^{46}$ This, of course, was in reference to Ontario legislation which then contained a severely restricted "Saturday-closing" exemption when compared with the new sabbatarian exemption. In the same vein, Seaton J.A., for the British Columbia Court of Appeal in Canada Safeway, dismissed as "flawed" an assertion that the effect of B.C.'s Sunday-closing legislation on retailers was exclusively relevant in determining whether the legislation infringed the Charter guarantee of religious freedom because "...it overlooks customers and employees whose rights as well as the retailer's rights must be considered". ${ }^{47}$ The Act was ultimately invalidated because it contained no exemption whatever to accommodate any non-Sunday-observing retailers. Edwards Books and Canada Safeway are not, I suggest, authority for the proposition that Sunday-closing legislation violates the Charter guarantee of religious freedom in the absence of imposing any significant economic burden on nonSunday-observing retailers. Indeed, there is appellate authority expressly and unequivocally opposed to that proposition. In considering a municipal by-law containing a broad sabbatarian exemption for non-Sunday observers, Cote J.A., delivering the judgment of the Alberta Court of Appeal in the London Drugs case, expressed no doubt

45. See the comments of Boilard J. in $R$. v. Nouveautes Capisal Lsee., supra, note 35, at 70 (Que. S.C.). Compare, the observation of Dickson C.J.C. in Edwards Books, supra, note 4, at $742-743$ (S.C.R.), 22 (D.L.R.).

46. Edwards Books, supra, note 4 at 766 (S.C.R.) 40 (D.L.R.).

47. Supra, note 27, at 201 (B.C.L.R.), 24 (W.W.R.). 
that a significant economic impact on retailers was the sine qua non of establishing an infringement of Charter rights: ${ }^{48}$

This by-law has no effects which are either religious or discriminate for or against any religion's followers or non-believers. Every business affected may freely choose any day in seven that it will close and may choose the day after the fact, and may change the day from week to week.

It is unfortunate that this decision was not brought to Mr. Justice Southey's attention or, at any rate, was not dealt with in his reasons for judgment.

Apart from the foregoing, it would be questionable in any event whether the infringement on the religious freedom of non-Sunday-observing employees and consumers, identified by Southey J., achieves sufficient significance to render the amended Ontario legislation in contravention of Charter guarantees. Recent statutory and common law developments make it difficult to accept his reasoning that the Act significantly impacts on the religious freedom of employees because it "provides no protection for employees whose religion requires them to observe a day other than one on which their employer's business is required to be closed under the Act". ${ }^{49}$ In support, he curiously puts forward the example of a Jewish employee observing Saturday who is employed by a retailer required to close on Sunday. An economic impact is imposed by the legislation, he suggests, because the employee would only have the opportunity of working on five days a week whereas a Christian employee could work on six days. He fails to recognize, however, that the economic impact of Sunday-closing legislation on the non-Sundayobserving employee is unlike that on the non-Sunday-observing retailer as the opportunity of working on six days, albeit not necessárily for the same employer, is not preempted by the legislation. A Jewish retailer, for example, required by his religion to close on Saturdays and by legislation to close on Sundays necessarily incurs a significant financial burden owing to the combined mandates of religion and legislation. In the absence of legislation he could open six days a week whereas because of legislation and religion he is, in fact, restricted to five. The Jewish employee, on the other hand, is only required by religion to refrain from working on Saturdays. The legislation does not additionally require that he refrain from working on Sundays. Admittedly, in the absence of Sundayclosing legislation more Sunday retail employment opportunities might be available to the Jewish employee. Nonetheless, the specific impact made by the legislation as a whole

Supra, note 5, at 15.

Peel, supra, note, 6 at 296. His assertion fails to recognize that substantial protection is actually afforded to the majority of employees affected by the new sabbatarian exemption via companion amendments to Ontario's Employment Standards ACt (S.O. 1989, c. 4) which confer upon the employee a statutory right "to refuse any assignment of Sunday work that the employee considers unreasonable." Ontario's adoption of a "referee" mechanism to resolve employer-employee disputes with respect to unreasonableness and enumeration of the considerations which the referee may weigh in assessing reasonableness address concerns expressed by Dickson C.J.C. in Edwards Books: supra, note 4 at 773 (S.C.R.), 44 (D.L.R.). In addition, the S.C.C. held in Re Ontario Human Rights Commission et al. and Simpsons-Sears Lid. (1985), 23 D.L.R. (4th) 321, [1985] 2 S.C.R. 536, 64 N.R. 161, that under the Ontario Human Rights Code if an employee objects on religious grounds to working on a particular day, the employer must take reasonable steps, up to the point of undue hardship, to make alternate arrangements for that employee. 
must be considered. Absent the legislation, there is no guarantee that his specific employer would have been open for business, given that experience elsewhere indicates that Sunday would be a voluntary pause day of preference for many retailers in the community. ${ }^{\text {so }}$ Having regard to the usual transferability of retailing skills and the increased availability of alternative Sunday retailing opportunities made possible by the new sabbatarian exemption, the indirect burden imposed by the amended Ontario Act on non-Sunday-observing employees does not appear to attain a level of significance sufficient to constitute an infringement of $C$ harter rights guaranteeing freedom of religion or freedom from discrimination on the basis of religion.

Basically, the same arguments apply, perhaps even more cogently, to any assessment of the extent of the legislative impact on non-Sunday-observing consumers. Because Ontario's sabbatarian exemption, for example, now permits many large non-Sundayobserving retailers to open on Sundays, it attempts to minimize the burden previously imposed on non-Sunday-observing consumers who relied upon large retailers to supply them with foodstuffs conforming to religious dietary laws, a burden described by Dickson C.J.C. in Edwards Books as "particularly onerous"." While all Sunday-closing legislation de facto makes shopping less convenient for non-Sunday-observing consumers, it is doubtful, given the expansive nature of Ontario's new sabbatarian exemption, that this level of inconvenience achieves the requisite degree of significance to constitute a Charter infringement of their religious freedom.

\section{B. JUSTIFICATION}

After finding that the Ontario Act infringed on the freedom of religion of some retailers, employees and consumers, Southey J. acknowledged that the proper test to apply with respect to justification under s. 1 was that set out by Dickson C.J.C. in Edwards Books. That test, in turn, mandates a sequential analysis of the two requirements necessary to establish justification, viz., assessing, first, whether the legislative objective bears on a "pressing and substantial concern" sufficient to warrant overriding a constitutional right and, second, if so, whether the legislative means are proportional to that legislative objective..$^{52}$

Southey J. properly recognized that the legislative objective of the amended Ontario Act was precisely the same as that of its predecessor: ${ }^{53}$

I am quite satisfied that the objective of the amended Act is the secular one of providing retail workers with a pause day in common with others as was accepted in Edwards Books and Paul Magder Furs.

In assessing its importance, a majority of the S.C.C. in Edwards Books had no difficulty whatever in concluding that the same legislative objective was aimed at a "pressing and

See, e.g., the experience in Alberta and British Columbia. Supra, note 4 at 766 (S.C.R.); 40 (D.L.R.).

The Chief Justice's methodology clearly illustrates the sequential nature of the inquiry: see Edwards Books, supra, note 4, at 768-770 (S.C.R.), 41-43 (D.L.R.).

Peel, supra, note 6 at 298. 
substantial concern". Indeed, as noted earlier, Dickson C.J.C. considered it "self-evident", ${ }^{54}$ a view independently shared by La Forest J. $^{55}$ and which led the B.C.C.A. in Canada Safeway to the same "inevitabl[e] conclusion". ${ }^{56}$ Although Southey J. considered voluminous new evidence about attitudes to Sunday shopping, he also expressly noted that this additional evidence did not provide a basis for impeaching the findings of justification in Edwards Books. ${ }^{57}$ That should have obviated any need to assess de novo whether the promotion of the legislative objective was of sufficient importance to override a constitutional right and to bear on a "pressing and substantial concern". If the legislative objective of the amended Act was the same as that of its predecessor, as he recognized, and if, as he held, the new evidence was insufficient to establish that the factual basis for the findings of the S.C.C. in Edwards Books was outdated, the sequential analysis dictates that he should have accepted, without more, the importance of the legislative objective and gone on to assess whether the legislative means were proportional to it vis-a-vis the infringement of Charter rights which they entailed. Instead, only after he assessed the legislative means, specifically the "municipal option" exemption, did he conclude that the objective of a common pause day was not a "pressing and substantial concern." This, arguably, puts the judicial cart before the horse and, in effect, really concerns itself not with assessing whether legislative purpose is of sufficient importance but, rather, whether the Legislature has sufficiently achieved that purpose.

Even assuming the propriety of his departure from the sequential analysis, there is little to support Southey J.'s negation of the legislative objective's importance solely on the basis that the legislation gave municipalities the power to opt out. Surely there is no requirement that a concern be province-wide in order to satisfy the "pressing and substantial" threshold. It is trite to suggest that a concern can be pressing and substantial from the standpoint of the Legislative Assembly notwithstanding that it is pressing and substantial only for a particular area or areas of the province. Nor is there anything inherently improper in delegating legislative authority for that designation. This, in effect, is what happens under a legislative scheme, such as Alberta's, which leaves the decision to enact a uniform retailing pause day by-law up to each municipality. If any such by-law is required to pass the justificatory test under s. 1, the "pressing and substantial concern" would have to be established exclusively in reference to the specific municipality. If the Legislature's objective is to provide retail workers with a pause day in common with others in the community, is it not simply a matter of legislative choice whether "community" is defined in provincial or municipal terms?

The failure to appreciate the foregoing distinction also led Southey J. to conclude that the "municipal option" exemption failed to meet the second justificatory requirement, the proportionality test, set out in Edwards Books. That test requires that limiting measures (1) be rationally connected to the legislative objective, (2) impair Charter rights as little as possible, and (3) refrain from trenching so severely on those rights that the legislative

Ibid.

Supra, note 27, at 203 (B.C.L.R.), 126 (W.W.R.) per Seaton J.A. Compare R. v. Westfair Foods Lid. et al, supra, note 29, at 49 per Cameron J.A. (Sask. C.A.).

Peel, supra, note 6 at 305. 
objective is outweighed by the abridgement. To support his conclusion he focused exclusively on the rationality aspect, asserting that he could see "no careful design or rational connection to the common pause day objective in a scheme which leaves it to individual municipalities to determine the criteria to be applied in granting exemptions or requiring closing, or to proceed without establishing any criteria". ${ }^{58}$ His analysis is deficient in three important respects.

First, it fails to recognize that municipal by-laws, being delegated legislation, must ultimately pass Charter scrutiny, thus pre-empting the exercise of "unprincipled power" or "carte blanche". In this respect, there is little substantive difference between the permissive by-law making power contained in s. 4 of the amended Retail Business Holidays Act and that conferred upon Ontario municipalities under s. 211 of the Municipal $A c t^{59}$ permitting them to enact by-laws requiring the closing of shops for

a weekly holiday. It is not the constitutionality of such general enabling provisions that is really in issue. ${ }^{60}$ Rather, it is the resultant by-laws which are subject to Charter scrutiny. This was tacitly recognized by La Forest J. when he offered the following comments concerning Alberta's decentralized Sunday-shopping legislative scheme: ${ }^{.1}$

The Alberta Act, Municipal Government Amendment Act, 1985 (Alta.), c. 43, s. 31 (re-enacting s. 241 [of the Municipal Government Act, R.S.A. 1980, c. M-26]), contains enabling provision whose practical workings cannot be determined in the abstract. The simple fact is that what may work effectively in one province (or in a part of it) may simply not work in another without unduly interfering with the legislative scheme. (Emphasis added)

The proper approach is best illustrated in the London Drugs case, ${ }^{62}$ where the "practical workings" of the Alberta scheme were judicially scrutinized not in the abstract but in reference to a specific Sunday-closing by-law enacted by the City of Red Deer.

Second, Mr. Justice Southey's analysis loses sight of the fact that the proportionality inquiry must, itself, remain focused on how proportional the severity of the infringement on religious freedom is to the objective of providing retail workers with a pause day in common with others in the community. In other words, does the legislative scheme abridge freedom of religion as little as is reasonably possible? In this context it is especially significant that the delegated power to enact a "municipal option" exemption by-law is circumscribed vis-a-vis its potential impact on non-Sunday-observing retailers. This is mandated by the express override in the new sabbatarian exemption which, in effect, legislatively incorporates the exemption into every such by-law. ${ }^{63}$ Consequently, for reasons previously canvassed, the severity of the impact of such by-laws on s. 2(a) or

\footnotetext{
58. Ibid. at 308-309.

s9. R.S.O. 1980 , c. 302 as am.

60. Cf. R. v. Westfair Foods Lid., supra, note 29 (Sask. C.A.).

6I. Edwards Books, supra, note 4, at $801-802$ (S.C.R.), 72 (D.L.R.). Compare, the comments of Dickson C.J.C., at 772 (S.C.R.), 44 (D.L.R.), which are no less potent in the context of delegated legislation.

62. Supra, note 5 .

63. The opening words in s. 5 of the amended R.B.H.A. provide as follows: "Despite any other provision of this or any other Act or the by-laws or regulations under this or any other Act, ...[substantive enactment of religious exemption]."
} 
s. 15 Charter guarantees would be minimal at best. Ironically, Southey J. appears to have reached that same conclusion exclusively in reference to the new sabbatarian exemption which, he stated, reflected "a reasonable trade-off between different possible schemes"64 and, therefore, constituted a reasonable limit under s. 1. That finding renders his inexplicable failure to acknowledge the same significant limitation on the exercise of the municipal option exemption all the more perplexing.

Third, Southey J. fails to recognize that the Legislature must be given sufficient latitude to fashion its own legislative response to the Sunday-closing issue from a number of reasonable alternative schemes. In this regard, it is well to recall the admonition of Dickson C.J.C. in Edwards Books: ${ }^{.5}$

A "reasonable" limit is one which, having regard to the principles enunciated in Oakes, it was reasonable for the Legislature to impose. The courts are not called upon to substitute judicial opinions for legislative ones as to the place at which to draw a precise line.

If, as authority suggests, the legislature is able to forebear legislating a province-wide uniform closing law and, instead, permit municipalities to regulate the hours or days of business, within the constraints of the Charter, through by-law making authority, why should the Legislature not equally be at liberty to enact a uniform province-wide closing law and permit municipalities to exempt themselves from its application and impose their own regulatory regimes, subject always to Charter limitations? Chequerboarding would inevitably occur in either event owing to the fact that some municipalities would enact by-laws and some would not. The only substantive difference is in the default mechanism employed by the Legislature. In the former case, retailers may open by default unless they are by by-law required to close whereas, in the latter case, retailers must close by default unless they are permitted by by-law to open. In either case, the ultimate responsibility for determining whether uniform closing is a "substantial and pressing concern" within any given municipality and what to do about it within the parameters of the Charter rests at the local level.

\section{CONCLUSION}

The decision of Mr. Justice Southey in Regional Municipality of Peel v. Great Atlantic and Pacific Co. of Canada Ltd. et al, invalidating Ontario's Retail Business Holidays Act, justifiably warrants national attention. While the decision is limited in its immediate impact to the province of Ontario, it potentially impacts on Sunday-closing legislative schemes in four provinces, including Alberta, that have municipal option features. The foregoing analysis strongly suggests that $P e e l$ is wrongly decided for a number of reasons. First, Ontario's amended R.B.H.A. imposes no burden of sufficient significance, within the meaning of Edwards Books, on the religious practise of non-Sunday-observing or nonChristian retailers and, in its absence, no Charter infringement on religious grounds can be established. Second, even if it could, the impact of the amended legislation on non-

6s. Supra, note 4, at 781-782 (S.C.R.), 51 (D.L.R.). La Forest J. also emphasized the importance of giving the Legislature adequate scope to achieve their objective: see 794-795 (S.C.R.), 67 (D.L.R.). 
Sunday-observing employees and consumers is of insufficient significance to constitute an infringement of their Charter-guaranteed religious rights. Third, and alternatively, if an infringement of Charter rights can be established, the proper application of both branches of the justificatory test set out by the S.C.C. in Edwards Books would uphold the prohibition and amended exemptions in the Act as a reasonable limit within $\mathrm{s} .1$ of the Charter. Given the paucity of precedent and compelling rationale to support Southey $\mathrm{J}$.'s decision in Peel, it is to be hoped that appellate review will re-establish that degree of predictability in the Charter analysis of Sunday-closing legislation that took nearly a decade of appellate caselaw to fashion. ${ }^{66}$

In a lengthy decision released on March 21, 1991 the Ontario Court of Appeal unanimously reversed the judgment of Southey J. Dubin C.J.O. (Morden A.C.J.O., Krever, and Griffiths JJ.A. concurring) held that, for the reasons suggested in this commentary, the amended Ontario Act did not contravene religious freedom as guaranteed under s. 2 of the Charter, viz., that the new Sabbatarian exemption negated any adverse impact on non-Sunday observing retailers, that any infringement on the religious freedom of non-Christian retailers owing to the designation of Christmas and Good Friday as "holidays" was trivial and insubstantial, that the burden imposed on non-Sunday observing customers was reduced, if not eliminated, by the new Sabbatarian exemption and that the Act did not impose upon employees any substantial increased cost of practising their religion because, in the absence of legislation, there was no compunction for employers to open on Sundays. In the alternative, the Chief Justice addressed the justificatory issue employing the sequential analysis as suggested in this commentary. He held that the amended Act could be justified under $\mathrm{s} .1$ of the Charter because its legislative objective, like that of its predecessor, was directed towards a pressing and substantial concern notwithstanding that it contained exemptions and that its application might be restricted to certain sectors or constituencies. On proportionality, the Chief Justice held that the amended Act was less intrusive than its predecessor. Finlayson J.A. delivered separate reasons for judgment. Present indications are that leave to appeal to the S.C.C. will be sought. 